\title{
Cross-linguistic Analysis of Metaphorical Conceptions of dyua/dusza/duša ('soul') in Slavic Languages (Russian, Polish, and Croatian) ${ }^{1}$
}

\author{
KRISTINA ŠTRKALJ DESPOT ${ }^{1}$, INNA SKRYNNIKOVA ${ }^{2}$, \\ JULIA OSTANINA OLSZEWSKA ${ }^{3}$ \\ Institute of Croatian Language and Linguistics (Croatia) ${ }^{1}$; Volgograd State \\ University (Russia) ${ }^{2}$; University of Warsaw (Poland) ${ }^{3}$
}

\section{Introduction}

The idea that an individual is made up of various elements - some physical and some spiritual, and that soul is the distinguishing mark of living things seems to be universally present in all philosophical and spiritual systems since ancient times. The broader meaning of a soul as not only animating the body but being morally, cognitively and intellectually significant (responsible for functions like thought, perception, desire, and moral qualities) was already firmly established in the fifth century Greek usage. The concept of the soul was of primary concern to various Pre-Socratic thinkers, and to ancient philosophers like Plato, Aristotle, Epicurus, and the Stoics. Their theories of soul have shaped later theoretical developments in the writings of Plotinus and other Platonists, Thomas Aquinas, and Immanuel Kant, among others. Our inner life has remained the subject of research of various different contemporary approaches as well.

The concept of soul serves as a cue to revealing and understanding existential representation of human immaterial nature in different cultures, thus being one of the basic elements which forms the linguistic picture of the world fixed in national mentality. A great body of research is based on the idea that the concept of soul concerns several key issues in human life: the source of life, cognition and emotion, personality traits, social relationships, and human destiny. The concept of soul has been actively studied from mythological, religious, philosophic,

\footnotetext{
${ }^{1}$ This work has largely benefited from George Lakoff's and Eve Sweetser's insightful comments and ideas and from the work of the Metaphor Seminar at the Berkeley Linguistic Department. We are also thankful to the participants in The 38th Annual Meeting of the Berkeley Linguistics Society for their questions and comments.
} 


\section{KRISTINA ŠTRKALJ DESPOT, INNA SKRYNNIKOVA, Julia OSTANINA OLSZEWSKA}

cognitive, sociological and psychological perspectives. A number of authors have analyzed the concept of soul from the point of view of its linguistic representation in different languages: Wierzbicka (1989; 1992); Shmelev (1997); Mikheev (1999); Vardanyan (2007); Kolesnikova (2011); Tszin (2010); Uryson (1999); etc. Our research differs from the previous ones in the sense that it is cross-linguistic, corpus-based and cognitive in nature. This paper is an attempt to carry out a cross-linguistic, corpus-based and cognitive analysis of the concept in question in three Slavic languages: Russian (East Slavic), Polish (West Slavic), and Croatian (South Slavic).

The Slavic words for soul are derived from Proto-Slavic *duxb with suffix $-j-$ $a$ (Proto-Indo-European $* d h o u s i \bar{a}$ ), and the meaning is connected with breathing and blowing, which is common in many Indo-European languages, and hence refers to the vital breath, the animating principle.

The fact that the Russian word dusha ('soul') has much wider range of use and much higher frequency than the English word soul has been noticed and extensively analyzed by Wierzbicka (1989). Since in other Slavic languages dusha has a similar range of use and frequency as its equivalent in Russian, we assume that the relevant conceptual structure is not just Russian but pan-Slavic. To see what that conceptual structure actually looks like we will provide a detailed corpus-based analysis of linguistic manifestations of the conceptual metaphors and metonymies for $\partial y u a / d u s z a / d u s ̌ a$ ('soul') as the target domain in Polish, Russian and Croatian corpora ${ }^{2}$.

The basis of our theoretical and methodological approach is Conceptual Metaphor Theory as presented in Lakoff and Johnson (1980), and then further developed and applied in Lakoff (1987), Sweetser (1987), Grady (1997), Lakoff and Johnson (1999), Kövecses (2000; 2010), Feldman (2006), and Lakoff (2009), among many others

Lakoff and Johnson (1999) and Sweetser (2004) have presented an extensive analysis of the metaphorical conceptions of our internal structures and the embodiment of spiritual experience. Our analysis is largely based on their results.

The research corpus consists primarily of Russian National Corpus, Polish National Corpus and Croatian Language Repository.

\footnotetext{
${ }^{2}$ We are well aware of the fact that data collected by corpus-based analysis does not represent linguistic reality - it is a "corpus reality filtered through subjectivity of intuitive judgments (ŽicFuchs 2009:98)." Therefore we have combined a corpus-based analysis with our judgments as native speakers and with the systematic introspection (as defined by Wierzbicka 1980:21). Nevertheless, we think that the corpus reality filtered through intuitive judgments is more suitable as a research tool than just intuitive judgments which are not confirmed in the corpus reality.
} 


\title{
Metaphorical Conceptions of душа/dusza/duša ('soul')
}

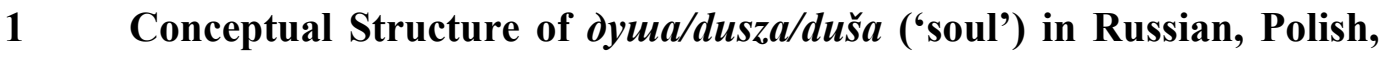 and Croatian}

\begin{abstract}
"What we have called variously the Subject or the disembodied mind is called in various religious traditions the Soul or Spirit. In spiritual traditions around the world, the Soul is conceptualized as the locus of consciousness, subjective experience, moral judgment, reason, will, and, most important, one's essence, which makes a person who he or she is." (Lakoff and Johnson's 1999:563)
\end{abstract}

The concept of soul is tightly connected with religion, spirituality and philosophy, and this apect has been the focus of the linguistic analysis of that concept in Slavic languages so far. We will not entirely neglect this perspective, but will be more interested in the embodied experience behind the conceptual structure of dusha.

Lakoff and Johnson (1999:267-289) have revealed that we have a "system of different metaphorical conceptions of our internal structure" and there are a "small number of source domains that the system draws upon: space, possession, force and social relationships." Their analysis of the metaphorical conceptions of our inner lives is based on fundamental distinction between the Subject and one or more Selves, which was first introduced by Andrew Lakoff and Miles Becker (1992). Lakoff and Johnson (1999) have shown that metaphors for conceptualizing our inner lives are grounded in universal experiences and that we conceptualize the Subject as being person-like, with an existence independent of the Self. As they have pointed out, those metaphoric conceptions have a hierarchical structure with the general Subject-Self metaphor (conceptualization of person as bifurcated) at the first level and many more specific instances on other levels. They further point out (1999:562) that the natural concomitant of this metaphor is the metaphorical concept of mind separated from the body. This metaphor is crucial for our analysis.

In the Slavic languages in question, this conceptualization of the soul is indeed present, and there are linguistic expressions of conceptual metaphors of dusha as the locus of consciousness, reason, emotions, will, etc. This conceptualization is often bound with other conceptual metaphors in interesting ways (e.g., with conceptualization of a soul as either a person or a thing) and with other conceptual metaphors from other domains, as we shall see.

Very often in these languages the specific cases of Subject-Self metaphors (listed in Lakoff and Johnson 1999:269-289) are manifested too. ${ }^{3}$ And sometimes some other loci of reason, emotions, will, etc. are expressed in language, as for example Heart As The Locus Of Emotions, Head/Brain As The Locus Of Reason,

\footnotetext{
${ }^{3}$ These metaphors will not be of our interest in this article, but we will list a few Croatian examples to illustrate this: Suzdržao sam se da ga ne udarim ('I held myself back from hitting him'); Izvan sebe sam (literally: 'I am out of myself'); Rastresena sam danas (literally: I am scattered today); Saberi se! ('Pull yourself together!') etc.
} 


\section{KRISTINA ŠTRKALJ DESPOT, INNA SKRYNNIKOVA, Julia OSTANINA OLSZEWSKA}

Mind As The Locus Of Consciousness, etc. These other metaphors will not be subject to examination in this article.

\section{General Disembodied Soul Metaphor}

The concept of a disembodied Soul, like that of a disembodied Mind, is metaphorical: it arises from embodied experiences that we have throughout our life. ${ }^{4}$ And this requirement of the Soul (and Mind) being embodied is "no small matter" because it contradicts the crucial beliefs of many religions around the world based on transmigrations of souls and reincarnation, as Lakoff and Johnson (1999:563) pointed out. But being aware of the fact that "metaphors may create realities for us, especially social realities" as stated repeatedly in Lakoff and Johnson (1980:156) it is not surprising that in many languages, including the three Slavic languages in question, disembodied Mind and/or Soul is a religious and social reality which is very well reflected in language as well.

This metaphor is combined with the conceptions of soul as being either the locus of emotions, moral judgment, will, essence or reason. Depending on the type of locus and combining these metaphors with either reification or personification we get many specific levels manifested by numerous linguistic metaphors as we shall see in the examples.

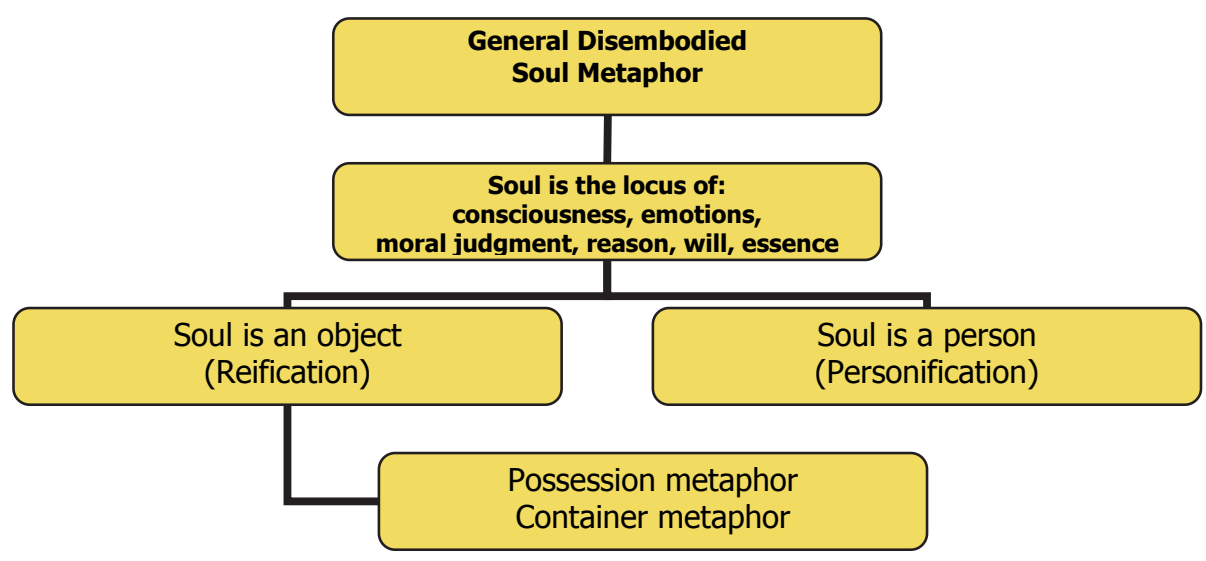

\footnotetext{
${ }^{4}$ Lakoff and Johnson (1999: 565): "The embodied mind is part of the living body and is dependent on the body for its existence. The properties of mind are not purely mental: They are shaped in crucial ways by the body and brain and how the body can function in everyday life (...). The mind is not merely corporeal but also passionate, desiring and social. It has a culture and cannot exist culture-free. It has a history, it has developed and grown, and it can grow further. It has unconscious aspect, hidden from our direct view and knowable only indirectly. Its conscious aspect characterizes what we take ourselves as being. Its conceptual system is limited; there is much that it cannot even conceptualize, much less understand. But its conceptual system is expandable: It can form revelatory new understandings."
} 


\subsection{Possession Metaphor}

In addition to the general metaphor of disembodiment, the possession metaphor (PARTS ARE POSSESSIONS) is at least equally pervasive underlying all other metaphorical conceptions of soul. Within the cognitive model of a person ${ }^{5}$, the soul is conceptualized as being a part of a person, and therefore we get the metaphor: A PERSON POSSESSES A SOUL (which lives in his/her body). A person is the "owner" of a body and a soul (we say my body, my soul). The owner and his/her soul usually both live in the body, which is other metaphor and we will go back to it later. The PARTS ARE POSSESSIONS metaphor is most probably universal, based on existing cross-linguistic empirical evidence. The linguistic manifestations of most other specific cases of conceptual metaphors are often bound with this metaphor.

This means that regardless of weather the soul is conceptualized as a person or a thing (and more specifically, what kind of a person and what kind of a thing), it always belongs to somebody. That possessive meaning is always grammaticalized with possessive pronouns or case markers.

PARTS ARE POSSESSIONS + cognitive model of a person where Soul and Body are parts of a person $=$ A PERSON POSSESSES A SOUL (WHICH LIVES IN HIS/HER BODY)

CRO: moja duša ('my soul'); tvoja duša ('yours soul'); njegova duša ('his soul'); RUS: наша душа ('our soul'); моя душа ('my soul'); POL: nasza dusza ('our soul'); moja dusza ('my soul'); jego/jej dusza ('soul of his/her');

PARTS ARE POSSESSIONS + PSYCHOLOGICAL PAIN IS PHYSICAL PAIN =

\section{SOUL IS A PHYSICAL PART OF THE BODY THAT CAN HURT}

CRO: I samoga me duša boli! ('My soul hurts'); zar vas ne boli duša? ('Doesn't your soul hurt?'); RUS: Что-то у меня душа болит за него. ('I don't know why but my soul hurts because of him'); Что делать, не знаю...душа болит, любовь умирает. ('I don't know what to do ... my soul hurts and my love is dying').

A less common version of this metaphor is that A PERSON POSSESSES A SOUL (which lives in some other person's body). This metaphor is a very specific instantiation of the possession metaphor used in conceptualizing love

\footnotetext{
${ }^{5}$ Figurative conceptions of dusha are tightly related to cognitive model or models of a person. One cognitive model of a human being is dual. According to that model, human beings consist of two entities: body and soul. A body is a visible, physical part, and a soul includes the whole inner life of a human being (or referring again to Lakoff and Jonson's citation: consciousness, subjective experience, moral judgment, reason, will, and one's essence). There is also another cognitive model of a human being within which the soul does not have such a broad meaning since its 'tasks' are assigned to other 'parts' of a person: this model includes at least body (the visible, physical part), heart (the locus of emotions), mind (the locus of reason and counciousessness), self and soul.
} 


\section{KRISTINA ŠTRKALJ DESPOT, INNA SKRYNNIKOVA, Julia OSTANINA \\ OLSZEWSKA}

relationships. Its experiential bases might be connected with the cultural frame of bringing one's material possessions into one's interpersonalrelationship (marriage), which then become the material possessions of your partner as well (shared property). ${ }^{6}$

Since the Soul is metaphorically conceptualized as being a Possession, it can also be shared with the partner in a love relationship. This linguistic metaphor is probably bound with the conceptualization of the SOUL AS THE LOCUS OF ONE'S ESSENCE. It is not only two people in love who share one soul, but also larger social groups united by some important (nonphysical) property.

PARTS ARE POSSESSIONS + SOUL IS THE LOCUS OF ESSENCE + Cultural frame of sharing possessions while being in a love relationship = A PERSON POSSESES A SOUL (WHICH LIVES IN SOMEONE ELSE'S BODY)

CRO: moja duša je tvoja ('My soul is all yours'); njegova duša tvoja duša ('His soul is your soul'); RUS: Моя душа - теперь твоя душа ('My soul is now yours'); POL: Kiedy w moich najskrytszych marzeniach roiłem o duszy, która będzie moją, kiedy czułem, że dusza taka istnieje, nie znałem Cię ('When in my most secret dreams I longed for the soul, which would be mine when I felt that such soul exists, I did not know you');

SOUL IS THE LOCUS OF ESSENCE + metonymy Sharing A Soul/Possession stands for Intimacy $=$ CLOSE SOCIAL/RELIGIOUS/NATIONAL GROUP SHARE ONE SOUL

CRO: Mnoštvo vjernih jedno su srce i jedna duša. ('People who believe in God are one soul and one heart'); Kad slušaš ove pjesme, shvatiš što znači slavenska duša, to drugi narodi nemaju ('When you listen to these songs, then you can understand what the Slavic soul means, other nations don't have something like that'); POL: ... dowiem się czegoś o stanie, w jakim znajduje się dusza naszego Narodu. ('I'll know something about the state of our Nation's soul').

\subsection{What Kind of an Object is Soul?}

Conceptualizing the Soul as being an Object (reification) is very common and very general. Reification is an ontological metaphor by its cognitive function, which means that it does not provide much cognitive structuring for the target domain (Lakoff and Johnson 1980:25-33; Kövecses 2010:38). This metaphor is almost always bound with other metaphors, to provide more structure for this abstract target domain by means of structural or more specific metaphors. As a result of the binding of different conceptual metaphors, and sometimes of cultural frames as well, we get many specific cases of linguistic metaphors where Soul is conceptualized as different kind of objects: a valuable object, a brittle object, a hot, cold or burning object, etc. We will now go through the examples and see what conceptual metaphors determine the properties of an Object/Soul on the

\footnotetext{
${ }^{6}$ Sweetser (2004:38): "Marriage makes a permanent metaphorical and spiritual link out of the temporary physical joining of sexual intercourse."
} 
linguistic level:

\begin{abstract}
SOUL IS THE LOCUS OF ESSENCE + ESSENCE IS VALAUBLE + SOUL IS AN OBJECT = SOUL IS A PRECIOUS/VALUABLE OBJECT (THAT CAN BE LOST, STOLEN OR SOLD)
\end{abstract}

CRO: duša zlata vriedi ('his soul is as valuable as gold'); RUS: Продать душу ('to sell your soul');

SOUL IS THE LOCUS OF SUBJECTIVE EXPERIENCE (EMOTIONALITY) + EMOTIONAL VULNERABILITY IS PHYSICAL FRAGILITY + SOUL IS AN OBJECT = SOUL IS A BRITTLE OBJECT

RUS: ... когда-то в детстве моя душа хрустнула под тяжестью огромного альбома, посвящённого давно исчезнувшей культуре охотников за мамонтами ('at some point in my childhood my soul cracked under the weight of a huge German album, devoted to the mammoth hunters culture.'); CRO: U podsvijesti se nalazi sve što se u vašu dušu urezalo i što nosite sa sobom, što može biti bol, patnja, traume, a može se raditi i o nečemu što se zove slomljena duša ('In your subconscious, there is everything that has been engraved in your soul and that you carry with you, it can be suffering, pain, traumas, and it can as well be what we call broken soul');

SOUL IS THE LOCUS OF REASON (MEMORY) + MEMORIZING IS WRITING + SOUL IS AN OBJECT= SOUL IS A PHYSICAL OBJECT MADE OF A SOLID SUBSTANCE (SO YOU CAN ENGRAVE ON IT)

CRO: Sve to je vrlo kratko trajalo, a duboko nam se u dušu urezalo ('all that did not last long, but it was deeply engraved into our soul');

SOUL IS THE LOCUS OF SUBJECTIVE EXPERIENCE (EMOTIONALITY) + Image

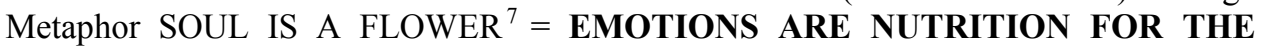
SOUL

RUS: душа вянет ('soul is wilting'); POL: Moja dusza rozkwitła obok Cię. ('My soul is blooming when I am next to you');

SOUL IS THE LOCUS OF SUBJECTIVE EXPERIENCE (EMOTIONALITY) + EMOTIONS ARE FLUIDS + SOUL IS A CONTAINER + KNOWING IS SEEING = SOUL IS A RIVER/SEA ${ }^{8}$

CRO: da duša moja, na istočišće stvora teče ('my soul flows towards the spring of being'); dirala ga u dno duše ('she touched him to the bottom of his soul'); RUS: душа его - вот тот самый невидимый колодец, который стал пуст, сух, а теперь потихоньку вбирает в себя воду. ('His soul is a kind of invisible well, which became dry and empty, and now is absorbing water little by little').

A very common specific case of the Reification metaphor in all languages in

\footnotetext{
${ }^{7}$ This metaphor is connected with our experience and knowledge about plants and flowers: we are well aware that if a flower lacks essential nutrition, it wilts, and when the nutrition is of a good quality, flower is blooming. Whatever soul is wilting for, it used to be something essential for it.

${ }^{8}$ The concept of a soul as a river or sea is bound with the primary metaphor KNOWING IS SEEING in a sense that what is on the surface of a river/sea is easily accessible by vision/knowledge, and what is at the bottom of a sea/soul is something that is usually accessible only by applying considerable amount of additional effort.
} 


\title{
KRISTINA ŠTRKALJ DESPOT, INNA SKRYNNIKOVA, Julia OSTANINA \\ OLSZEWSKA
}

question is the one of the Soul being an entity with different degrees of warmth (it can be cold, warm, hot or burning), depending on the intensity of emotions and passions (this is an instantiation of the primary metaphors EMOTIONAL IS WARM, RATIONAL IS COLD). The intensity of emotions is expressed by the degree of warmth, which is conceptualized by a scalar image schema (Feldman 2006:138) and the SOUL IS THE LOCUS OF EMOTIONALITY metaphor.

\begin{abstract}
AFFECTION IS WARMTH; RATIONALITY IS COLD + SOUL IS THE LOCUS OF SUBJECTIVE EXPERIENCE (EMOTIONALITY) + SOUL IS AN OBJECT + SCALE IMAGE SCHEMA = SOUL IS A WARM/HOT/BURNING/COLD OBJECT

RUS: Знаешь, что у нас есть тёплое? Судьба и сердце, жизнь и душа. И тем более свет от Бога. ('Do you know what warmth we have? Fate and heart, life and soul. And the light from God'); CRO: Bio je on neobično darovit i uman mladić, a njegova vruća $i$ zanosna duša nosila je u svemu biljeg Bogom odabrana pravoga pjesnika ('He was an exceptionally talented and smart young man, and his hot and ecstatic soul carried the mark of a real poet chosen by God'); POL: kiedy dusza jest jeszcze rozpalona i jest obdarzona dobrem i resztkami minionego pocieszenia ("yet when the soul is still burning up and is blessed with the good and the remnants of the last consolation); CRO: Hladnu dušu imaju oni koji su nevoljeni od drugih i nesposobni podijeliti osjećaje i najdublje duševne strune s drugima ('Those who are not being loved by others and who are not able to share their feelings and the deepest strings of their souls with others, they have a cold soul');
\end{abstract}

SOUL IS THE LOCUS OF MORALITY + MORALITY IS PURITY + SOUL IS AN OBJECT $=$ SOUL IS A CLEAN OBJECT

CRO: Moja je duša čista ('My soul is clean'); RUS: Когда он про себя писал - душа моя чиста - это было истинной правдой. ('When he wrote - My soul is pure- it was true').

\subsection{Container Image Schema: SOUL IS CONTAINED WITHIN A BODY; SOUL IS A CONTAINER}

Conceptualization and experience of a body as a container is inherent to human beings as Lakoff and Johnson $(1980,1999)$ and Johnson (1987) have shown and the experiential basis for this conceptualization is obvious: we fill and empty our digestive tract and our internal organs are contained inside the surface of our skin, flash and bones. The concept of soul being contained within the body is probably universal, and it is widely used in Slavic languages as well. It is very common that we conceptualize all our nonphysical experiences as being a part of our inner life, and inner means, of course, in the body.

BODY IS A CONTAINER FOR THE SOUL

CRO: Duša prebiva u mojem tijelu ('My soul dwells in my body'); POL: Jak niemowlę u swej matki, jak niemowle - tak we mnie jest moja dusza ('As an infant in his mother -as is my soul in me').

In the Slavic languages in question this general metaphor is very often 


\section{Metaphorical Conceptions of душа/dusza/duša ('soul')}

linguistically expressed, but there are also many more and very interesting specific cases of this metaphor which, taken together, form a complex image in which the soul is metaphorically conceptualized as a person living in a house/body. The soul can move within that house, and it can even leave that house and move to another. Usually it rests in the upper and central part of the body (most often soul is visible in someone's eyes), but under the influence of fear or other uncontroled event it can move to the peripheral parts of the body (heels) and then it can "come to its place again." The mouth is understood as being an opening to the container (door to the house) and when soul leaves the house, it leaves through mouth (There is an expression in Croatian: Duša mi je bila na jeziku 'My soul was on my tongue'), which means being very close to death. This means that a soul can be in its normal location, it can go out of a normal location and then go back to it. We defined this specific metaphor as NORMAL STATE OF THE SOUL IS THE NORMAL LOCATION OF THE SOUL(which is connected with the primary metaphor STATES ARE LOCATIONS). ${ }^{9}$ These are all examples of the specific cases of the general BODY IS A CONTAINER FOR THE SOUL metaphor:

BODY IS A CONTAINER FOR THE SOUL (inference: soul can vacate from one container /body and move to another)

CRO: Ako se moja duša poslě smèrti, polag pojamah dušoselbe, u tělo kojeg kurira preseli, to će bit za me pravi pakao ('If according to the concept of reincarnation my soul after my death moves to the body of some courier, it is going to be real hell for me'); POL: Prawdopodobnie moja dusza zamknięta była w ciele człowieka, który spadł z tej kamienicy. Moje koszmary to wspomnienia z poprzedniego wcielenia. ('Probably my soul has been enclosed in the body of a person who fell from that building. My nightmares are the memories of the previous incarnations');

BODY IS A CONTAINER FOR THE SOUL (inference: soul is visible in person's eyes)

POL: Z jej oczu promieniuje dusza spokojna i subtelna, jak ów niebieski dymek unoszący się znad filizanek kawy na jej obrazach ('Her soul radiates from her eyes calm and subtle, like the blue smoke/vapour floating above the coffee cups on her paintings'); RUS: душа смотрит из карих Таниных глаз. ('her soul was looking at me from Tanja's brown eyes');

\section{SOUL IS CAPABLE OF MOVING WITHIN BODY}

RUS: От некоторого внутреннего центра душа движется вовне ... к материальному миру, в котором, по предположению, все процессы представляют собой нечто автоматическое" ("From some inner center the soul is moving towards the material world where supposedly all the processes are something automatic'); CRO: Sva mi je duša sišla u pete. ('My whole sole descended to my heels');

\footnotetext{
${ }^{9}$ In Lakoff and Johnson (1999: 274) the Location Self metaphor is described, but there the control of Subject over Self was conceptualized as being in a normal location. However, it seems that in our examples control is not crucial, altough it is often the case that the unusual state is caused by something external over which the Subject has no control.
} 


\title{
KRISTINA ŠTRKALJ DESPOT, INNA SKRYNNIKOVA, Julia OSTANINA OLSZEWSKA
}

TO HAVE YOUR SOUL ON YOUR TONGUE IS TO BE CLOSE TO DEATH

CRO: Duša mi je bila na jeziku, a život na tankoj niti. ('His soul was on his toungue, and his life was hanging on a very thin fibre');

\begin{abstract}
STATES ARE LOCATIONS and NORMAL STATE OF THE SOUL IS NORMAL LOCATION OF THE SOUL

RUS: Душа не на месте ('Soul is not in its place'); POL: Jedno zimne piwko i dusza wróci na swoje miejsce ('One cold beer and the soul will be back in its place'); CRO: treba mi tvoj oproštaj da mi duša bude na mjestu ('I need your forgiveness so that my soul can go back to its place').
\end{abstract}

Another very general conception of a soul is that of a sOUL itself being a CONTAINER. This conception is bound with metaphor PROTECTION IS CONTAINMENT, as described in Sweetser (2004:30), who points out that the important purpose of physical containment is to protect contents. As she argues, the experiential basis for this metaphorical mapping is the fact that our vital organs are protected by being contained within our body by flesh and bones, but also our everyday experience of putting something fragile in a box, or store something in a drawer, or locking a door, etc. There are special cases of this metaphor where SOUL IS A CONTAINER FOR EMOTIONS, and given the fact that the exposure of emotions in Western cultures is seen as vulnerability, the need to close those emotions in the container and make them invisible to others is logical. This concept involves primary metaphor KNOWING IS SEEING as well; that is why the soul container may be OPENED or CLOSED, or LIGHT or DARK in our examples. As Sweetser states, "in the understanding of Self, we see our strongest emotions as a source of vulnerability; anyone who affects them has an important (and potentially dangerous) effect on our whole psyche. We therefore try to allow only trusted people to affect these essential feelings, hoping they will not 'hurt' us psychologically." This need to control and hide emotions is not universal; it is typical of (modern) Western cultures. Aspects of control are very well described in Kövecses (2003). Sweetser's model of SELF as a CONTAINER in the above described sense includes these metaphors: ESSENTIAL, EMOTIONAL SELF IS THE (FRAGILE, VULNERABLE) CONTENTS OF A CONTAINER; PROTECTIVE SOCIAL RESERVE IS A CONTAINER; TRUSTED FRIENDS ARE PEOPLE ALOWED TO OPEN THE CONTAINER; FEARED EMOTIONAL HURT IS FEARED DAMAGE OR LOSS OF CONTAINER'S CONTENTS. All of the latter are relevant for the CONTAINER metaphorical concept of SOUL in Slavic languages.

Given that SOUL is conceptualized as a CONTAINER, it is not surprising that it can contain other souls as well, in some cases. This concept is used to describe a very close relationship, usually a love relationship. This conceptual metaphor is manifested in all Slavic languages in question. The concept of one soul being contained within another has the inference of not only protection, but also of tight closeness: 
SOUL IS A CONTAINER

RUS: Кино́- э́то здо́рово, но настоя́щая любо́вь живёт не в кино́, а в душе́. ('Movies are great, however real love doesn't live in a movie, but in the soul'); POL: a tu taki psalm zaczyna wdzierać się w dusze jak robak. ('and here such psalm begins to penetrate the soul like a worm'); CRO: Ljubica rad tog poljubca nije samo ćutila njeki osobiti stid u duši svojoj, nego je također od tog časa sasvim drugu privrženost i nagnuće osjećala prama Petru ('Ljubica not only felt some special kind of shame in her soul but also, from that moment, she felt some other kind of attachment and affection towards Petar.');

SOUL IS A CONTAINER + SOUL IS THE LOCUS OF SUBJECTIVE EXPERIENCE $($ EMOTIONALITY $)+$ SOUL IS A CONTAINER FOR EMOTIONS + EMOTIONS ARE FLUID CONTENT OF A CONTAINER $=$ SOUL OF AN EMOTIONAL PERSON IS A FULL CONTAINER; SOUL OF AN EMOTIONLESS PERSON IS AN EMPTY CONTAINER

CRO: Njihova je duša prazna ko smijeh bludnica, a smijeh beživotan ko slovo zakona ('Their soul is empty like a prostitute's laugh, and their laughing is lifeless like the letter of the law'); POL: pożywamy Chrystusa, a dusza napełnia się łaską i otrzymuje zadatek przyszłej chwały ("we receive Christ, and the soul is filled with grace and receives a pledge of future glory');

SOUL IS A CONTAINER FOR EMOTIONS + KNOWING IS SEEING = A VISIBLE SOUL'S CONTENT IS IN THE OPEN CONTAINER; AN INVISIBLE SOUL'S CONTENT IS IN THE CLOSED CONTAINER

CRO: njena duša se otvara za prvi put; njena put je još svježa, ('Her soul is opening itself for the first time, her skin is still fresh'); duša im je oboma bila zatvorena za onoga drugog ('both their souls were closed one for another'); RUS: Вы общительны открыты навстречу миру и людям, у вас “душа нараспашку” ('You're so sociable, open to the world and people, your soul is always unbuttoned');

\section{AN INVISIBLE SOUL'S CONTENT IS IN THE DARK CONTAINER}

RUS: В общем, не знаю, чужая душа, как известно - потёмки. ('In short, I don't know it, as someone else's soul is darkness'); CRO: Možda ću jednom shvatiti mračnu noć tvoje duše ('I might one day be able to understand dark night of your soul').

\section{Soul Is A Person metaphor - Personification}

Personification is one the most pervasive conceptual metaphors in general, and that is the case with the concept of SOUL in Slavic languages as well. General ontological SOUL IS A PERSON metaphor has many special cases in which the personified soul has a great variety of human properties which, taken together, form an interesting image. Pervasively in the corpora the SOUL IS A PERSON conceptual metaphor is bound with SOUL IS THE LOCUS OF SUBJECTIVE EXPERIENCE (EMOTIONALITY), which reflects in linguistic metaphor SOUL IS A PERSON THAT FEELS: Fear, Shame, Pain, Sorrow, Joy, Passion, Desire, Lust, etc. Uncommonly, the SOUL IS A PERSON conceptual metaphor is bound with SOUL IS THE LOCUS OF REASON which gives the linguistic metaphor SOUL IS A PERSON THAT THINKS, UNDERSTANDS, REMEMBERS, etc. Sometimes personification is bound with SOUL IS THE LOCUS OF MORALITY. These are the examples: 


\title{
KRISTINA ŠTRKALJ DESPOT, INNA SKRYNNIKOVA, Julia OSTANINA OLSZEWSKA
}

\begin{abstract}
SOUL IS A PERSON + SOUL IS THE LOCUS OF REASON = SOUL IS A PERSON THAT REASONS, THINKS, UNDERSTANDS, REMEBERS

RUS: Мужская ... душа помнила о тайности. Она, душа моя, ждала ублаготворения и в то же время пужалась его. ('This man's soul remembered those secrets and was waiting for gratification, but at the same time it was afraid of it.'); POL: dusza nasza rozróżnia wyobrażenie samej siebie od wyobrażeń innych przedmiotów ('Our soul distinguishes the idea of itself from the idea of images of other objects'); Dzieła Twoje są przedziwne, i wie o tym dusza moja ('your works are wonderful, and my soul knows that'); CRO: ova moja duša je: mislila, osjećala ('This soul of mine was thinking and feeling');

\section{SOUL IS A PERSON + SOUL IS THE LOCUS OF SUBJECTIVE EXPERIENCE $($ EMOTIONALITY $)=$ SOUL IS A PERSON THAT FEELS:} FEAR/SHAME/SORROW/JOY/LUST

CRO: Duša mi osjeća strah ('My soul feels fear'); RUS: И христианская её душа, несмотря на роскошь отдыха, испытывала лёгкий стыд. ('And her Christian soul felt some slight shame, despite the luxurious rest she was having'.); POL: Smutna jest moja dusza aż do śmierci; zostańcie tu i czuwajcie ('My soul is sorrowful until death comes: stay here and watch.'); RUS: Особенно ежели день солнечный - душа поет от радости! ('Especially when the day is sunny, the soul sings with joy'); CRO: Duša mi je tako vesela ('My soul is so happy'); duša ti se smije ('Your soul is laughing');

Sva duša izgarala joj od želje za dragim ('All her soul was burning with desire for her dear love'); Često, prečesto nije se mogao, dakako, nadjačati da mu krv ne usplamti i da mu sva duša i sve tijelo silno ne požudi posjed krasnoga mladoga stvora što ga je gledao ('Often, very often he could not prevent his blood from burning and his whole soul from strongly desiring to posses this beautiful, young creature he was looking at');
\end{abstract}

SOUL IS A PERSON + SOUL IS THE LOCUS OF MORALITY = SOUL IS A PERSON THAT IS MORAL/IMMORAL

CRO: Oprosti mojoj griješnoj duši ('Forgive my sinful soul'); Ta se opaka ropska duša drznu igrati se kralja. ('That evil, servile soul dared to impersonate a King'); RUS: Ведь у него не твоя подлая душа, чтобы за деньги продать любовь свою! ('Indeed, his soul is not evil as yours is, so that he could sell his love for money').

\section{$5 \quad$ Soul metonymies}

Conceptual metonymy is a cognitive process in which one conceptual entity, the vehicle, provides mental access to another conceptual entity, the target, within the same domain, or cognitive model. ${ }^{10}$ Within the cognitive model of a Person, which consists of a Body and a Soul (and possibly some other properties as well), the Soul often serves as the vehicle that provides mental access to the Person as a whole. This PARS PRO TOTO (part-for-whole) metonymic concept is very basic and common, and it is a part of the ordinary way we think and act as well as talk (Lakoff and Johnson 1980:37). Not surprisingly, its manifistations appeared very often in the corpora used in our research. Here are some examples:

\footnotetext{
${ }^{10}$ For more about conceptual metonymy, see for example in Lakoff and Johnosn (1980); Kövecses (2010), Lakoff (1987), Lakoff and Turner (1989), Langacker (1991, 1993), Gibbs (1994) etc.
} 
PARS PRO TOTO

SOUL FOR THE PERSON

CRO: Niti duša se nigdě neukaza. ('There was not a single soul there'); Vode mi dajte ako je koja duša ovdje. ('If some soul is here, please bring me some water'); POL:

Kolejna dusza zgnieciona pięścią alkoholu ('Another soul got crushed by alcohol').

As was the case with the examples illustrating conceptual metaphors, in the linguistic expressions of the conceptual metonymy the metaphor SOUL IS THE LOCUS OF EMOTIONALITY plays a crucial role, and in this case SOUL IS THE LOCUS OF MORALITY is important as well, for PARS PRO TOTO metonymy is often bound with one of these metaphors. As a result of the former binding we get the linguistic realization SOUL FOR THE EMOTIONAL PERSON, and the result of the latter metaphor is SOUL FOR THE MORAL PERSON.

SOUL FOR THE PERSON metonymy + SOUL IS THE LOCUS OF MORALITY metaphor $=$ SOUL FOR THE MORAL PERSON

CRO: Kata je inače dobra duša; ali sada izpod tvoga dostojanstva. ('Kata is usually a kind soul, but now below her dignity'); No vi ste posve nevina duša. ('You are a completely innocent soul');

SOUL FOR THE PERSON metonymy + SOUL IS THE LOCUS OF EMOTIONALITY metaphor $=$ SOUL FOR THE EMOTIONAL PERSON

POL: tyś jedna dusza, co odczuła ojcowskie strapienie i ból nie do stłumienia. ('you are the only soul, that felt his father's heartache and irrepressable pain'); RUS: Вы не знаете моего Сему. Это же такая душа! Нежный, чувствительный... ('You don't know my son Sema. He is such a good soul. Affectionate, sentimental...').

\section{Conclusion}

The analysis showed that the cultural model of dusha is indeed very similar in Russian, Polish and Croatian, and that it integrates bodily and cultural (especially religious) experiences.

In Russian, Croatian and Polish several very general conceptual metaphors are crucial for conceptualizing soul: the Disemebodied Soul metaphor, SOUL IS THE LOCUS OF EMOTIONALITY, Reification (with Posession metaphor and Container Image schema) and Personification. The Disembodied Soul Metaphor and The SOUL AS THE LOCUS OF SUBJECTIVE EXPERIENCE (emotionality) metaphors are the most important and pervasive in the conceptualization of SOUL in Slavic languages in question and we can infer that the "Slavic soul" is primarily the locus of emotionality.

\section{$7 \quad$ References}

Czin, L. 2010. Доминантные концепты душа и судьба в русских фразеологизмах в зеркале китайских [Dominant concepts of soul and destiny 


\section{KRISTINA ŠTRKALJ DESPOT, INNA SKRYNNIKOVA, Julia OSTANINA OLSZEWSKA}

in the Russian phraseology mirrored in Chinese]. Ph.D. University of Minsk, Minsk.

Feldman, J. 2006. From Molecule to Metaphor. Cambridge, MA: Bradford MIT Press.

Gibbs, R. 1994. The Poetics of Mind: Figurative Thought, Language, and Understanding. Cambridge: Cambridge University Press.

Grady, J. 1997. Foundations of Meaning. Ph.D. thesis, University of California, Berkeley, Berkeley, CA.

Kolesnikova, V. V. 2008. Художественный концепт "душа" и его языковая репрезентация: на материале произведений Б. Пастернака. [Artistic concept of "soul" and its linguistic representation: based on works by Boris Pasternak]. Scientific library of theses and abstracts (http://www.dissercat.com /content/khudozhestvennyi-kontsept-dusha-i-ego-yazykovaya-reprezentatsiyana-materiale-proizvedenii-b).

Kövecses, Z. 2000. Metaphor and Emotion: Language, Culture, and Body in Human Feeling. Cambridge: Cambridge University Press.

Kövecses, Z. 2010. Metaphor: A Practical Introduction. Oxford: Oxford University Press.

Lakoff, G. 1987. Women, Fire, and Dangerous Things. Chicago: University of Chicago Press.

Lakoff, G. 2009. The Neural Theory of Metaphor. In R. Gibbs, ed., The Cambridge Handook of Metaphor and Thought, New York: Cambridge University Press.

Lakoff, G. and M. Johnson. 1980. Metaphors We Live By. Chicago: University of Chicago Press.

Lakoff, G. and M. Turner. 1989. More Than Cool Reason. University of Chicago Press.

Lakoff, G. and M. Johnson. 1999. Philosophy in the Flesh. New York: Basic Books.

Lakoff, A. and M. Becker. 1992. Me, Myself and I. Manuscript. University of 
California, Berkeley.

Langacker, R. 1991. Foundations of Cognitive Grammar. Vol. 2: Descriptive Applications. Stanford, CA: Stanford University Press.

Sullivan, K. and E. Sweetser. 2009. Is "Generic is Specific" a Metaphor? In Fey Parrill, Vera Tobin and Mark Turner, eds. Meaning, Form and Body. Selected papers from the 2008 CSDL meeting. Stanford CA: CSLI Publications.

Sweetser, E. 1990. From Etymology to Pragmatics: Metaphorical and Cultural Aspects of Semantic Structure. Cambridge: Cambridge University Press.

Sweetser, E. 2004. The suburbs of your good pleasure: Cognition, culture and the bases of metaphoric structure. In G. Bradshaw, T. Bishop and M. Turner, eds., The Shakespearean International Yearbook, vol. 4: Shakespeare studies today. 24-55, Aldershot, England: Ashgate Publishing.

Uryson, E. V. 1999. Дух и душа: К реконструкции архаичных представлений о человек. [Spirit and soul: The reconstruction of archaic notions about people]. In E. V. Uryson, ed., Логический анализ языка. Образ человека в культуре и языке [Logical analysis of language. Image of a person in culture and language], 11-25, Moscow: Institute of linguistics of the Russian academy of sciences - Indrik.

Vardanjan, L. V. 2007. Этнолингвокультурный концепт "душа" в английской, русской и эрзянской языковых картинах мира [Ethno linguistic cultural concept of "soul" in English, Russian and Erzya language world model]. Ph.D thesis, Moscow State University, Moscow.

Wierzbicka, A. 1992. Semantics, Culture And Cognition. Oxford: OUP.

Wierzbicka, A. 1996. Semantics, Primes and Universals. Oxford: OUP.

Žic-Fuchs, M. 2009. Kognitivna lingvistika i jezične strukture: engleski present perfect. Zagreb: Nakladni zavod Globus

Dr. sc. Kristina Štrkalj Despot

Senior Research Associate

Institute of Croatian Language and Linguistics

Republike Austrije 16, HR - 10000 Zagreb, Croatia

kristina.despot@berkeley.edu 
KRISTINA ŠTRKALJ DESPOT, INNA SKRYNNIKOVA, Julia OSTANINA OLSZEWSKA

Dr. Inna Skrynnikova

Associate Professor

Department of Professional Intercultural Communication

Volgograd State University

100 University Avenue, 400062, Volgograd, Russia

innavskr@berkeley.edu

Dr. Julia Ostanina Olszewska

Associate Professor

Institute of Applied Linguistics

University of Warsaw

ul. Browarna 8/10, 00-311 Warszawa, Poland

j.ostanina@berkeley.edu 